\title{
A minireview on the contrast avoidance model of worry and generalized anxiety disorder
}

\author{
Alireza Rashtbari ${ }^{1}$, Fayegh Yousefi ${ }^{2}$, Omid Saed $^{3}$ \\ 1-MA Student of Clinical Psychology, Department of Clinical Psychology, Medical school, Zanjan University \\ of Medical Sciences, Zanjan, Iran. ORCID: 0000-0001-5324-2175 \\ 2-Associate Professor, Department of Psychiatry, Faculty of Medicine, Kurdistan University of Medical \\ Sciences, Kurdistan, Sanandaj, Iran. ORCID: 0000-0001-5503-3326 \\ 3-Assistant professor, Department of Clinical Psychology, Faculty of Medicine, Zanjan University of Medical \\ Sciences, Zanjan, Iran (Corresponding Author). ORCID: 0000-0002-6070-6203Ｅ-mail: o.saed@zums.ac.ir
}

Received: $14 / 05 / 2019$

Accepted: 24/08/2019

\begin{abstract}
Contrast Avoidance model claims that the main fear of individuals with generalized anxiety disorder is a negative emotional contrasts (shifts) and they use worry to create and maintain the negative and stable emotional state, so in this way, they could avoid from a negative emotional contrast. On the other hand, being in a negative emotional state, increases the likelihood of experiencing a positive emotional contrast and negative reinforcement due to a positive emotional contrast, maintains the worry process. the aim of present article is to a brief review on the Contrast Avoidance model, review of the studies supporting its tenets, and comparing the Contrast Avoidance model with present models of worry and generalized anxiety disorder. At the end, research suggestions are presented as future direction for this model.
\end{abstract}

Keywords: Contrast avoidance model, Generalized anxiety disorder, Worry, Minireview

How to cite this article : Rashtbari A, Yousefi F, Saed O. A minireview on the contrast avoidance model of worry and generalized anxiety disorder. Shenakht Journal of Psychology and Psychiatry. 2019; 6 (4): 37-54 .URL: http://shenakht.muk.ac.ir/article-1-689-fa.pdf

Copyright ( 2018 the Author (s). Published by Kurdistan University of Medical Sciences. This is an open access article distributed under the terms of the Creative Commons Attribution-Non Commercial License 4.0 (CCBY-NC), where it is permissible to download, share, remix, transform, and buildup the work provided it is properly cited. The work cannot be used commercially without permission from the journal. 


\section{مرورى كوتاه بر مدل اجتناب از تغيير نكر انى و اختلال اضطراب فراكير}

\section{عليرضا رشتبرى'، فايق يوسفى ؛ اميد ساعدَّ}

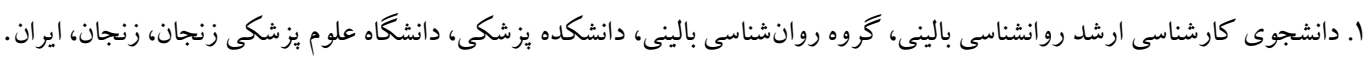

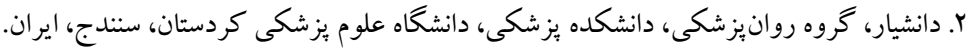

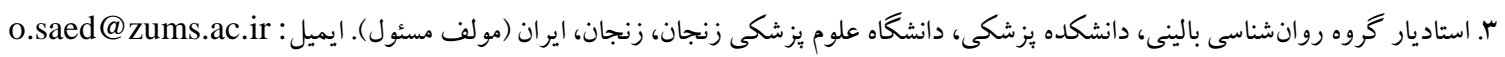

مدل اجتناب از تغيير ادعا مى كند كه ترس اصلى افراد مبتلا به اختلال اضطراب فراخير (اختلال اضطراب فراخير) تغيير هيجانى إنى

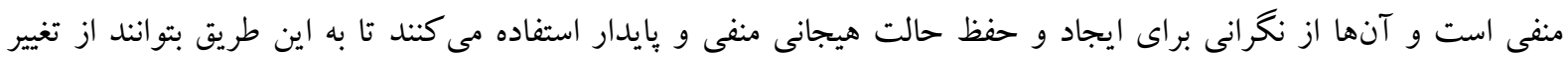

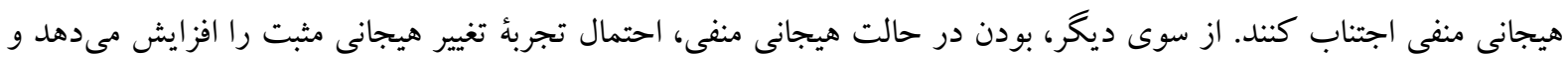



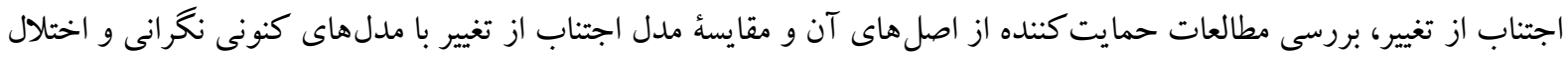

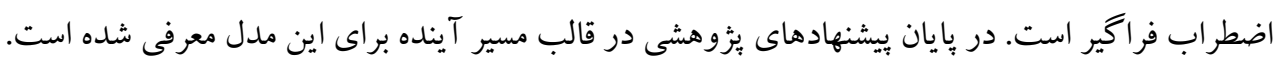
كليدوازهها: مدل اجتناب از تغيير*، اختلال اضطراب فراكير، نغرانى، مرور كوتاه

*طى نامهنكارىهايى كه با نظريه يردازان مدل اجتناب از تغيير صورت گرفت، وازههاى "change" و "alteration، را به عنوان معادلى براى وازٔة

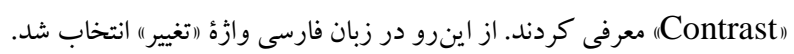


اضطراب فراگير، بيش از بيمارىهاى جسمى مانند

مقدمه

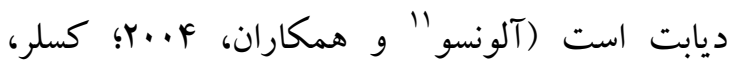
اختلال اضطراب فراخير'، با نخر انى مزمن، افراطى و

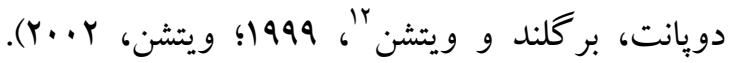
غيرقابل كنترل در مورد شمارى از موضوعات و

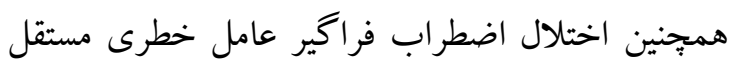

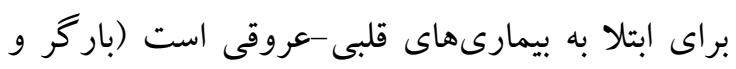

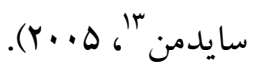
در مقايسه با درمان شناختى رفتارى كلاسيك، دارو درمانى در درمان اختلالات اضطرابى اثربخشتر است،

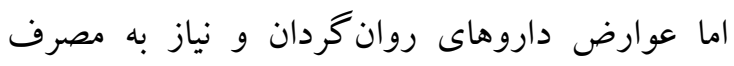

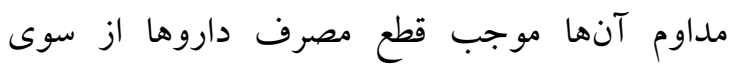
بيماران و باز گشت مجدد علائم اختلال مىشود (باندلو

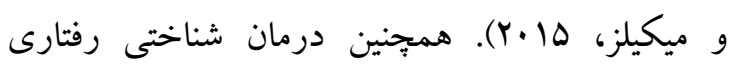
مى تواند تنها در •هـ٪ بيماران علائم اختلال را به طور

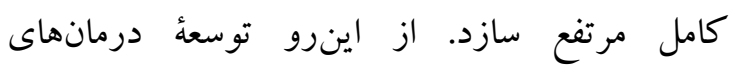
روانشناختى اثربخش در اين حوزه از اهميت حياتى برخوردار است. در طى سالهاى اخير مطالعات قابل توجهى در اين راستا صورت گرفته است و جند نظريه يرداز، مدلهاى نظرى خود را در تبيين اختلال اضطراب فراگير ارائه كردهاند. اين نظريهها در عين بردي

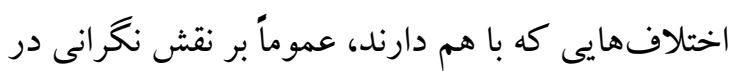
اجتناب از عاطفهُ منفى تأكيد كردهاند (بهار، دىماركو،

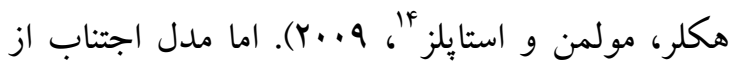

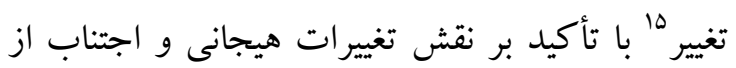
اين تغيير در هيجانها، در تحول و تداوم اختلال

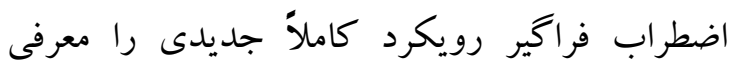
اضطراب، گوش به زنكى و علائم بدنى همراه آن مشخص مى شود (انجمن روانيز شكى آمريكا'، سا •.Y).



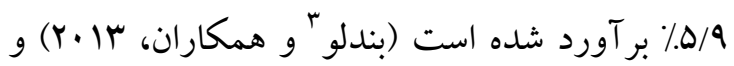

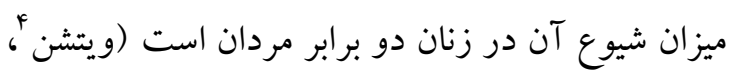

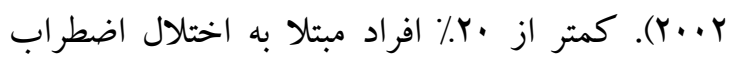
فراكير بدون درمان، بهبودى كامل علائم را تجربه

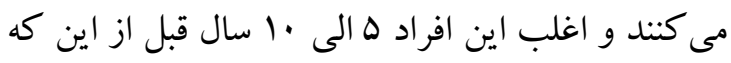
تشخيص اختلال اضطراب فراگير را دريافت كنند، واجد ملاككهاى تشخيصى اين اختلال بودهاند (بالنكر

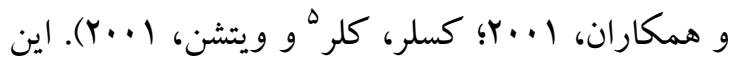
يافتها حاكى از اين هستند كه افراد مبتلا به اختلال اضطراب فراكير علىرغم بيامدهاى نگخرانى، قادر به رها كردن آن نيستند يا تمايلى به اين كار ندارند. در ميان

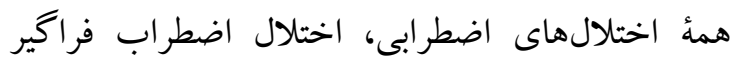

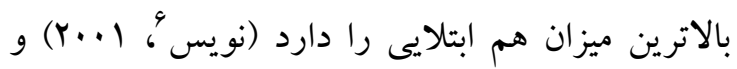

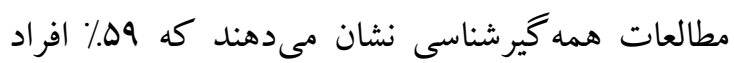

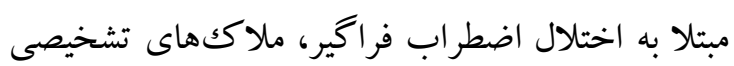
اختلال افسردگى اساسى ل را نيز برآورده مئى كنند

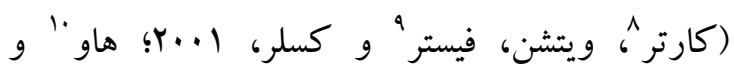

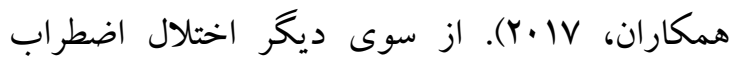
فراگير هزينههاى بسيارى بر فرد و جامعه تحميل مى كند آند و روزهاى كارى از دست رفته به سبب اختلال

\section{عوامل خطر ابتلا به اختلال اضطر اب فراتير}

\footnotetext{
${ }^{11}$. Alonso

12. Kessler, DuPont, Berglund, \& Wittchen

13. Barger \& Sydeman

${ }^{14}$. Behar, DiMarco, Hekler, Mohlman \& Staples

${ }^{15}$. Contrast Avoidance Model
}

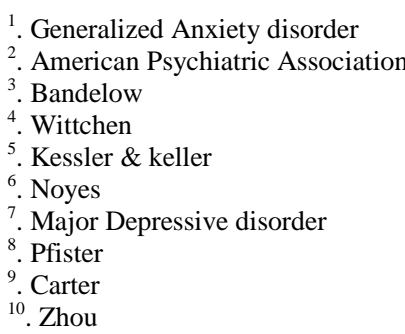


اختلالهاى هيجانى است (كلاسر ^و همكاران، 9..

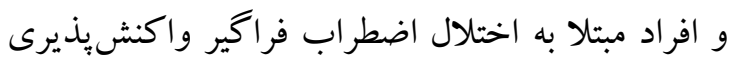
هيجانى بالايى رادر مواجهه با رويدادهاى منفى زندگى

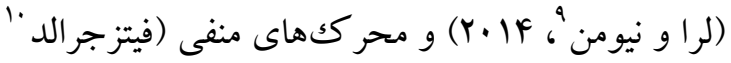

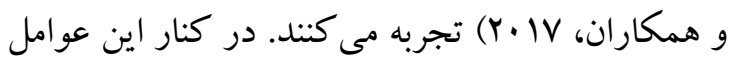
خطر، عامل سرشتى بازدارى رفتارى - عاملى سرشتى

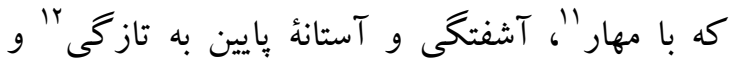
اجتناب از رويارويى با محر ككهاى جديد مشخص مى -



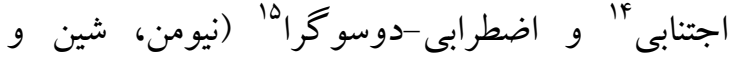

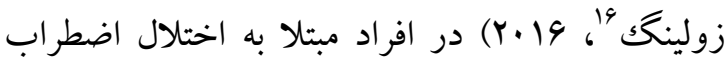

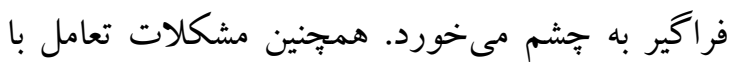



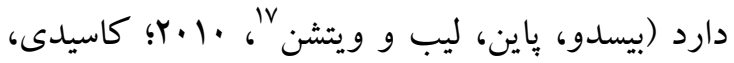

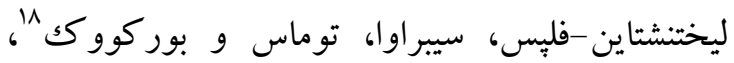

\section{مدل اجتناب از تغيير}

در روانشناسى شناختى نظريهاى با عنوان نظرئ تغيير عاطفى وجود دارد. اين نظريه توسط بيكن و همكاران

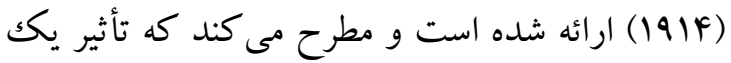

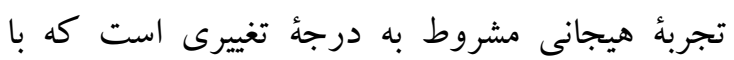
حالت هيجانى بيش آيند دارد؛ يعنى حالت هيجانى ييش آيند، تعيين كندهُ تأثير يكك تجربة هيجانى است.

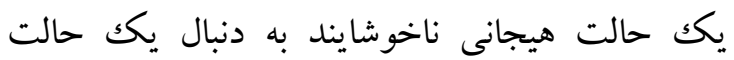
هيجانى خوشايند، به صورت ناخوشايندتر و به دنبال

\footnotetext{
${ }^{8}$. Glaser

9 . Llera \& Newman

${ }^{10}$. Fitzgerald

11. Restraint

${ }^{12}$. novelty

13. Kagan \& Snidman

${ }^{14}$. Avoidant

15. Anxious-ambivalent

${ }^{16}$. Newman, Shin, \& Zuellig

${ }^{17}$. Beesdo, Pine, Lieb, \& Wittchen

${ }_{18}$. Cassidy, Lichtenstein-Phelps, Sibrava, Thomas, \& Borkovec
}

در دوران تحول، عوامل خطر خاصى ممكن است افراد را به حساسيت هيجانى بالا، مشكلاتى در ادراكك و تنظيم هيجانات و حساسيت افراطى به تغييرات ' هيجانى ناكهانى از حالت هيجانى خنثى/مثبت به منفى هدايت كند و موجب شود كه افراد، براى كنترل هيجانهاى خود به راهبردهاى ناساز گارانهاى مانند نخرانى بناه بياورند. مطالعات نشان مىدهند كه افر اد مبتلا به اختلال اضطراب فراگير حساسيت هيجانى بالاترى دارند و در مقايسه با افراد مبتلا به اختلال اضطراب اجتماعى و كروه كنترل، جهرههاى داراى كمترين بار هيجانى را سريعتر تشخيص مىدهند (بويى 'و همكاران، Y. Y (Y). همجِين اين افراد در تنظيم هيجان دشوارى تجربه

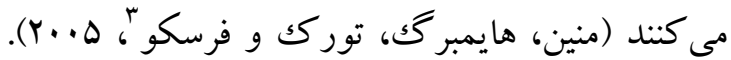
در رابطه با علل مشكلات تنظيم هيجانها در اين اختلال، عو امل گوناگونى شناسايى شدهاند. براى مثال افر اد مبتلا به اختلال اضطراب فراخير در مقايسه با افراد فاقد اين اختلال، به احتمال بيشترى خويشاوندان درجه

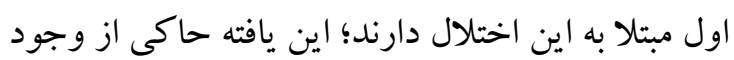
يكك مبناى زنتيكى براى اين اختلال است (شينل، ابنر و

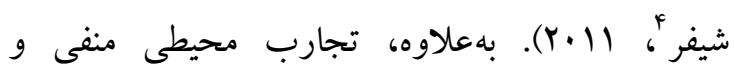
تجارب نامطلوب كودكى با واكنش يذيرى هيجانى بالا

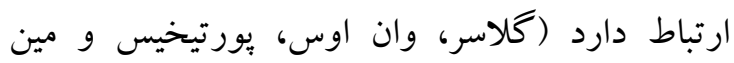

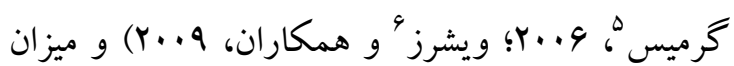
اين تجارب در افراد مبتلا به اختلال اضطراب فراگير بيش از افراد فاقد اين اختلال گزارش شده است

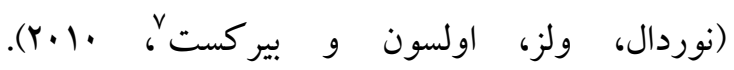
واكنشيذيرى هيجانى عامل خطرى براى ابتلا به

\footnotetext{
1 . Shifts

. Bui

${ }^{3}$. Mennin, Heimberg, Turk, \& Fresco

4. Schienle, Ebner, \& Schäfer

. Glaser, van Os, Portegijs, \& Myin-Germeys

${ }^{6}$. Wichers

. Nordahl, Wells, Olsson, \& Bjerkeset
} 
از افراد مبتلا به ساير اختلالهاى اضطر ابى و اختلالات خلقى، هيجانها را تهلديدآميز، شديد، خارج از كنترل، آزاردهنده و برانگيزنده تجربه مى كنند كه بر عملكرد رفتارى و حس بهزيستى آنها تأثير مى گذارد (منين،

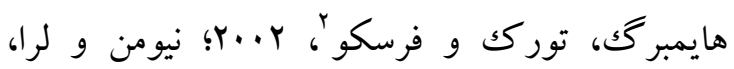

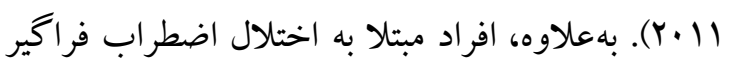
در ادراكك و مديريت هيجانهاى خود مشكل دارند و

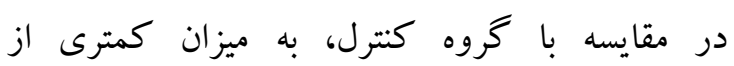
راهبردهاى ساز گارانه تنظيم هيجان استفاده مى كنند

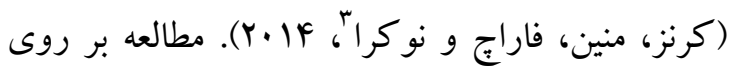
نمونههاى بالينى بزرگك نيز نشان مىدهند كه فقدان كنترل ادراكشده بر هيجانها در اختلال اضطراب برد فراكير بيش از ساير اختلالهاى خلقى و اضطر ابى است إته

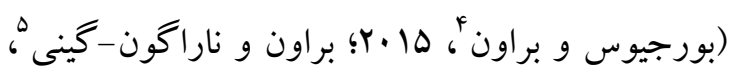

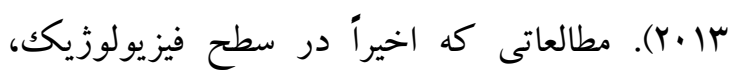
رفتارى، ذهنى و عصبشناختى صورت گرفتهاند، از اين جنبة مدل حمايت مى كنند كه تغيير منفى در افراد

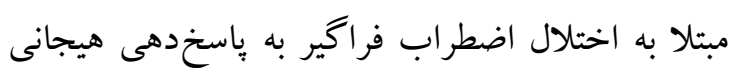
بيشتر و دشوارى در مقابله با هيجانها منجر مىشود. در يكك مطالعهُ تصويربردارى مغزى، افراد مبتلا به اختلال اضطراب فراگير به هنگام تجربه يك تغيير هيجانى منفى، در مقايسه با افراد مبتلا به اختلال اضطراب اجتماعى، اختلال پِانيكك و گروه كنترل سالم، اتصال بيشترى در مناطق مغزى مرتبط با هيجان (از جمله

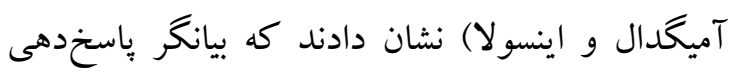
هيجانى بيشتر در اين افراد است. با اين حال، تنها در

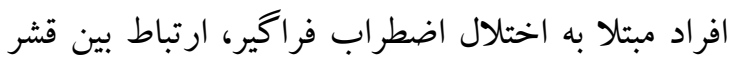
ييش ييشانى و و مناطق مرتبط با هيجان كاهش يافت كه

\footnotetext{
2. Mennin, Heimberg, Turk \& Fresco

3. Kerns, Mennin, Farach, \& Nocera

${ }^{4}$. Bourgeois \& Brown

5. Naragon \& Gainey

6. Prefrontal cortex
}

يكك حالت هيجانى ناخوشايند به صورت كمتر

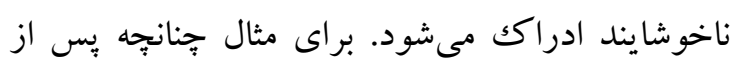

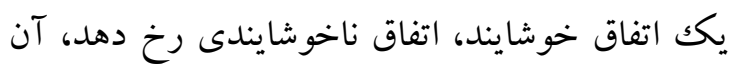
اتفاق ناخوشايند، بسيار ناراحت كننده ادراك مى شود؛

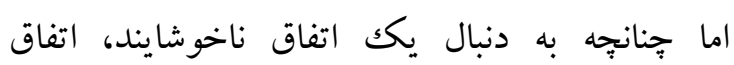
ناخوشايند ديخرى رخ دهد، كمتر ناراحت كننده به نظر

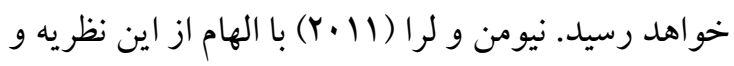

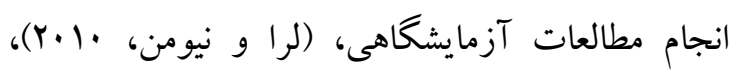

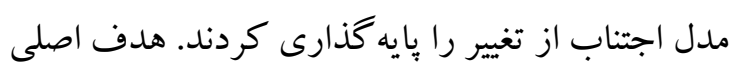

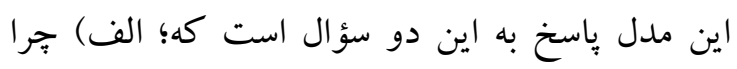

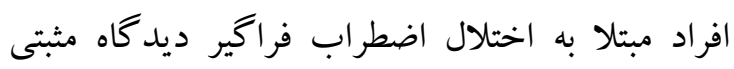

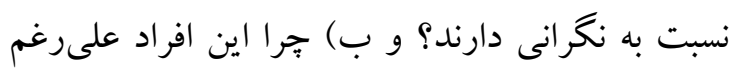

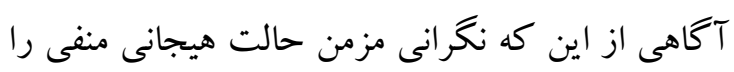
تداوم مىبخشد، باز هم به نكر انى ادامه مى دهند.

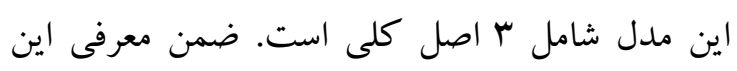
اصول، به مطالعاتى كه به طور مستقيم يا غير مستقيم از آنها حمايت مى كنند، اشاره مى كنيم. اصل اوّل مطرح مى كند كه ترس اصلى افراد مبتلا به اختلال اضطراب فراگير تغيير تند و سريع در هيجان منفى است؛ يعنى هستهٔ اصلى ترس اين افراد، تغيير

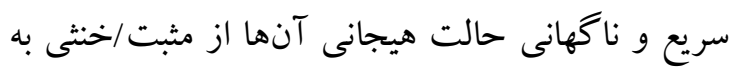
منفى است كه تغيير هيجانى منفى ناميده مى شود (نيومن

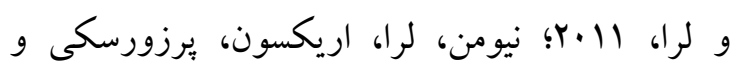

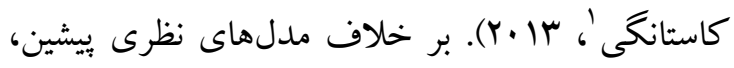
مدل اجتناب تغيير مطرح مى كند كه نخرانى نهتها

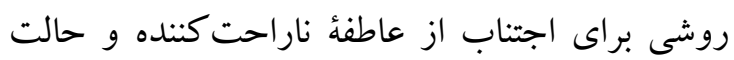
هيجانى منفى نيست، بلكه روشى براى ايجاد و حفظ روان هيجان منفى است، زيرا از اين طريق مىتوانند از تغيير هيجانى منفى اجتناب كنند. مطالعات بسيارى نشان

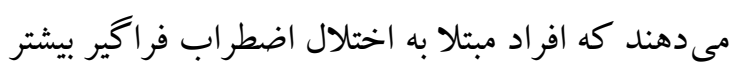

${ }^{1}$. Erickson, Przeworski, \& Castonguay 
ايجاد كنندهُ حالت هيجانى منفى است (نيومن و لرا،

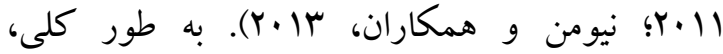
مطالعات از اين ادعا حمايت مى كنند كه نغرانى موجب برانخيختخى فيزيولوزيكى مىشود و افراد مبتلا

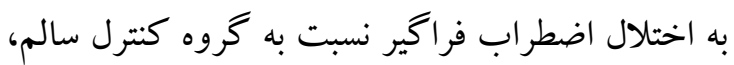
تغييريذيرى ضربان قلب بايينترى نشان مىدهند

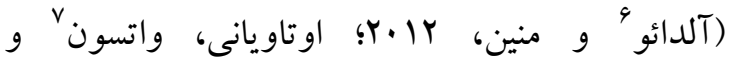

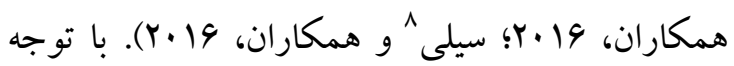

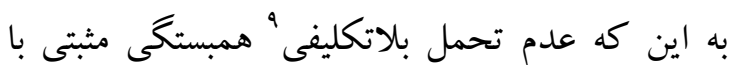

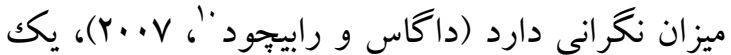
مطالعه نشان داد كه شركت كنند گان با ميزان عدم تحمل بلاتكليفى بالا، در طول تكليف القاكنندة نكرانى، تغيريذيرى ضربان قلب كمترى نشان دادند

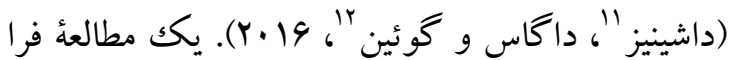
تحليل با بررسى .9 مطالعه مربوط به افكار تكرارشونده (نشخوار فكرى و نكرانى) نشان داد كه اين نوع شناخت با فشارخون سيستوليك و دياستوليك بالا، ضربان قلب بالا و تغييريذيرى ضربان قلب پايين ارتباط

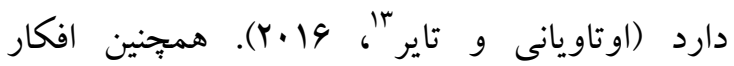
تكرارشونده بهبودى فيزيولوزيكك از استرس را مختل كرده و به تأخير مىاندازند (كايوبيانكو، موريس و و

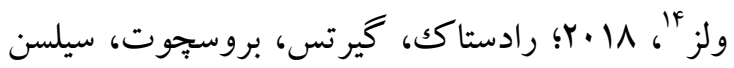

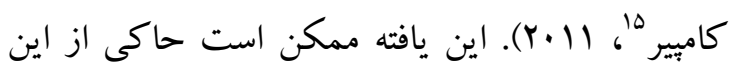
باشد كه نگرانى و نشخوار فكرى عملكردهاى مشابهى در ايجاد و حفظ بِاسخهاى فيزيولوزيكك به استرس دارند. همجنين مطالعاتى كه در محيطهاى طبيعى

\footnotetext{
6. Aldao

Ottaviani, \& Watson

${ }^{8}$. Seeley

${ }^{9}$. Intolerance of uncertainty

${ }^{10}$. Dugas \& Robichaud

11. Deschênes

${ }^{12}$. Gouin

13. Thayer

${ }^{14}$. Capobianco, Morris, \& Wells

${ }^{15}$. Radstaak, Geurts, Brosschot, Cillessen, \& Kompier
}

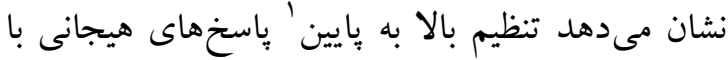

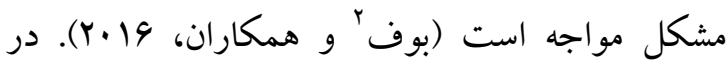
مطالعاتى كه اخيراً در ارتباط با اين مدل صورت هوت هورت كرفتهاند، مشخص شده است كه از نظر افراد مبتلا به

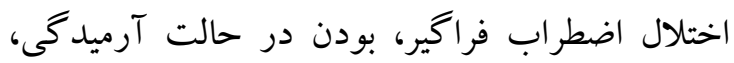
درست قبل از رويارويى با فيلم داراى محتواى ترس يا غمخينى، مقابله بّا آن را دشوارتر مىسازد و اين افراد نخر انى را در مقابله با هيجان منفى ناشى از رويارويى با بان آن فيلمها كمكك كندهتر مىدانند. در مقابل، شر كت كنند گان گروه كنترل گزارش كردند آرميدگى درست قبل از رويارويى با همان فيلمها، مقابله با هيجان منفى حاصل از آنها را آسانتر مى كند امّا، نغرانى تأثير معكوس دارد و موجب دشوارى در مقابله با آن

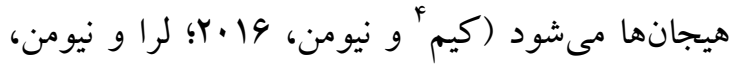

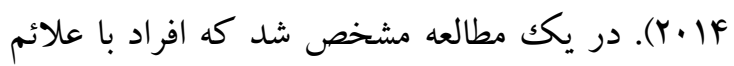
اختلال اضطراب فراگير بيشتر، تجارب تغيير هيجانى منفى را به عنوان بدترين اتفاق هفته درجهبندى كردند؛ با اين حال نخرانى تأثير اين تغييرات هيجانى منفى را

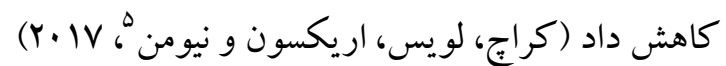
اصل دوّم مدل اجتناب از تغيير به اين صورت است كه نكر انى هيجان منفى را ايجاد و حفظ مى كند. اين ادعا لهاب بر اساس مطالعات زيادى صورت گرفته است كه نشان

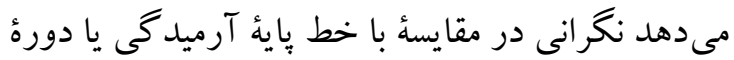

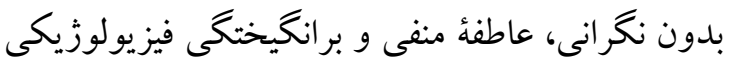

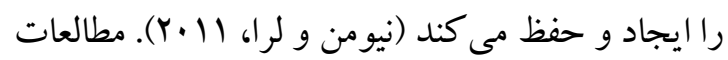

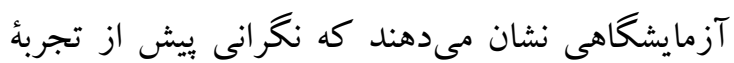
يكك رويداد منفى يا ناخوشايند، از افزايش حالت هيجانى منفى جلو گيرى مى كند، زيرا خود نكرانى،

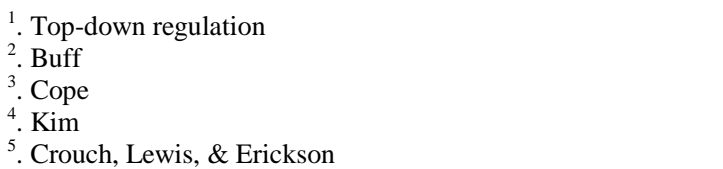


(Y.IV

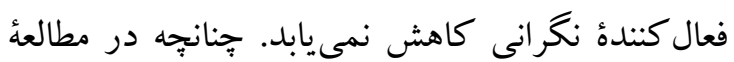

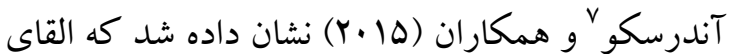

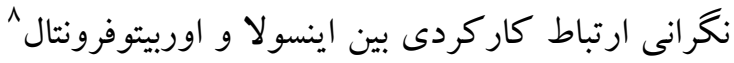

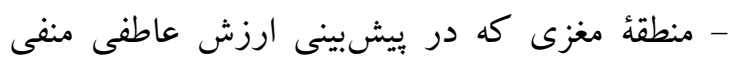
رويدادهاى آينده نقش دارد --رادر افراد مسن افزايش مىدهد. در مطالعاتى كه در رابطه با مدل اجتناب از تغيير انجام كرفتهاند، اين نكته تأييد شده است كه ويز گى فعال كنندة نكر انى موجب مى شود كه به به عنوان وسيلهاى براى اجتناب از تغيير منفى به كار كرفته شود.


تغيير منفى با حالت هيجانى منفى ارتباط دارد؛ اين در حالى است كه در اين مطالعه، نخرانى تأثير تغيير هيجانى منفى را كاهش داد (كراج، لويس، اريكسون و

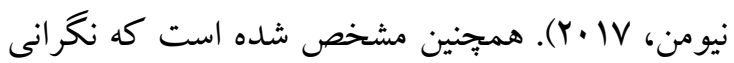
با حالت هيجانى منفى همزمان و مداوم ارتباط دارد و تغيير كمتر در هيجان منفى را در طول ساعت بعدى

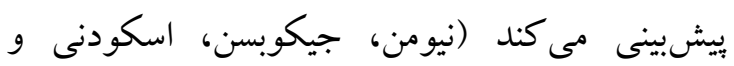

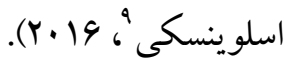
اصل سوّم اين است كه افراد مبتلا به اختلال اضطراب

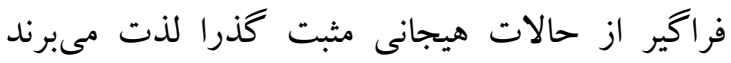
(تغيير هيجانى مثبت). همانكونه كه كفته شد، افراد

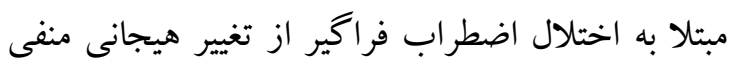
اجتناب مى كنند، بنابراين نمىتواند به مدتى طولانى

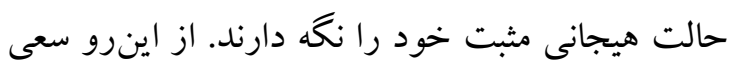
مى كنند يكك حالت هيجانى منفى و پايدار را براى خودشان ايجاد و حفظ نمايند. به اين ترتيب، نسبت به تجربهُ تغيير هيجانى منفى آسيب يذير نخواهند بود. امّا

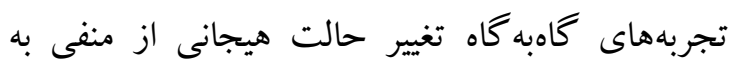

\footnotetext{
7. Andreescu

8. Orbitofrontal

9 . Jacobson, Szkodny, \& Sliwinski
}

صورت كرفته است از اين فرضيه حمايت مى كنند كه

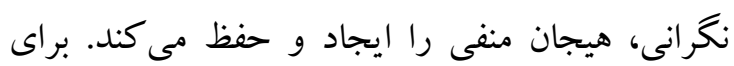

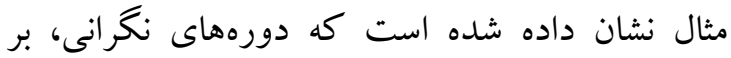
تغييريذيرى ضربان قلب همزمان و پِّآيند' تأثير

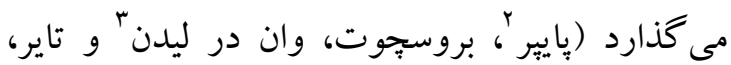

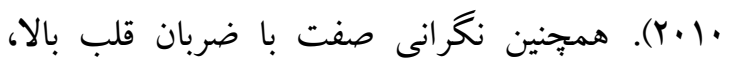
تغييريذيرى كمتر ضربان قلب و هدايت بوستى بالا در

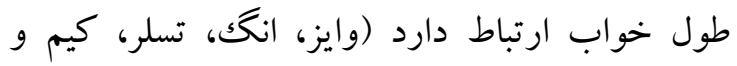

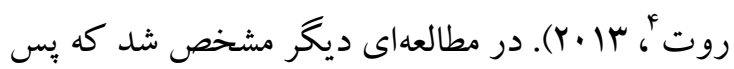



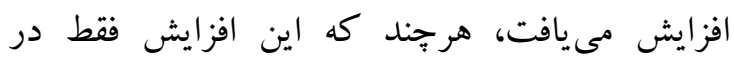

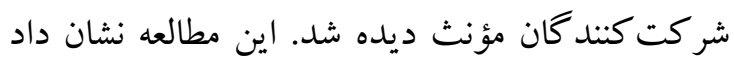
كه نخر انى، ميزان فعاليت محور هيبو تالاموس -هييوفيز غدد آدرنال را افزايش مىدهد (آربل، شابيرو، تيمونز، موس و ماركولين؛ فيزيولوزيكك بايدار مىشود. يكك مطالعهُ تصويربردارى مغزى كه با هدف فراهم كردن شواهد تأييد كننده براى مدل اجتناب از تغيير انجام شد، نشان داد كه در مقايسه

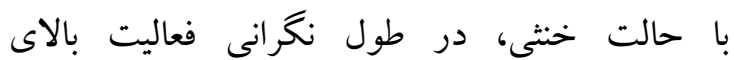
جشمخيرى در مناطق مغزى مرتبط با هيجان از جمله

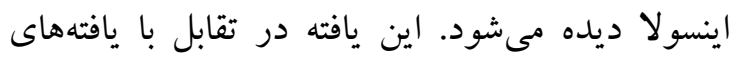
مطالعات بيشين است كه نشان داده بودند فعاليت


مىيابد. با در نظر گرفتن اين كه اينسولا در ادراكك حالتهاى احساس و يادآورى و ايجاد هيجانها نقش بانش

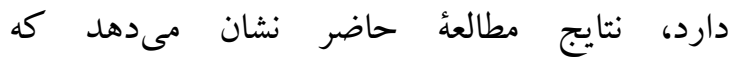
شر كت كنند كان، فعالانه نغرانى و نشخوار فكرى راصنا

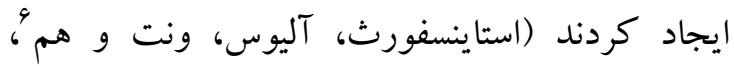

\footnotetext{
. Concurrent and subsequent

2. Pieper

3. Van der Leeden

${ }^{4}$. Weise, Ong, Tesler, Kim, \& Roth

5. Arbel, Shapiro, Timmons, Moss, \& Margolin

${ }^{6}$. Steinfurth, Alius, Wendt, \& Hamm
} 
اضطرابى، افراد مسن مبتلا به اختلال اضطراب فراخير در طول تكليف ارزيابى مجدد نخرانى، ارتباط بالاترى إنى را بين هستهُ فرا بطنى هو آميگدال راست نشان دادند. به به عبارت ديخر، تلاش براى كاهش نخر انى از سوى بـى اين افراد، راهاندازى براى پياسخ استرس بوده است

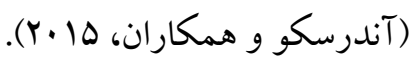

در دل مدل اجتناب از تغيير، فر آيند تغيير در هيجانها جاى دارد. بر طبق اين مدل، ترس اصلى افراد مبتلا به اختلال اضطراب فراگير، تغييرات هيجانى منفى است. آنها فعالانه از نكرانى براى ايجاد و حفظ يك حالت

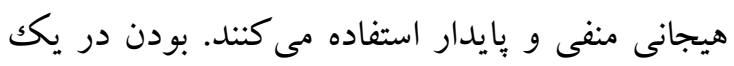

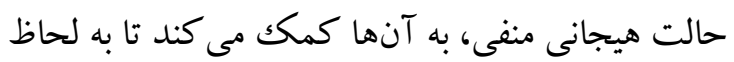

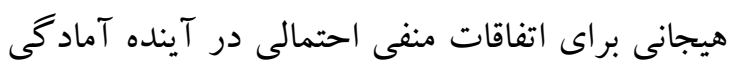
داشته باشند و از تغيير هيجانى منفى ناخهانى اجتناب لهنى كنند. به عبارت بهتر، افراد مبتلا به اختلال اضطراب فراخير همواره (ابه مرگك مى گيرند تا به تب راضى بهى شوندا). اين افراد به جاى اين كه به خودشان اجازه تجربهُ هيجانهاى متنوع را دهند و تغييرات هيجانى از مثبت/خنثى به منفى را تجربه كنند، ترجيح مىدهند

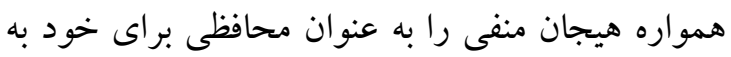
كار گيرند. براى اين افراد بهترين راه براى اجتناب از از

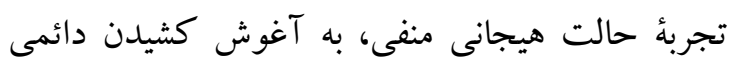

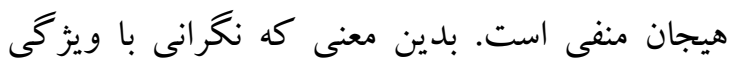
برانكيزنده خود، افراد مبتلا به اختلال اضطراب فراخير را در يك حالت گوش به زنكى و اضطراب نغه مىدارد و جنانجه اتفاق بدى روى دهد، آنها افزايش شديد و ناخهانى در ميزان هيجان منفىشان تجربه

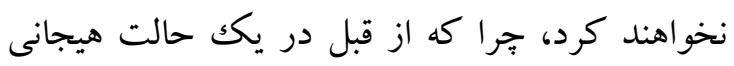
منفى قرار دارند. اين به اجتناب از تغيير هيجانى منفى

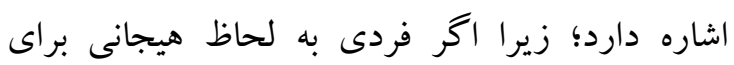

\footnotetext{
5. Paraventricular nucleus
}

خنثى/مثبت يعنى تغيير هيجانى مثبت براى اين افراد، دربردارندهُ تقويت منفى است؛ زيرا در اين هنگ امثام از ميزان آشفتخى ناشى از نكرانى كاسته مىشود و نكرانى آنها تسكين مىيابد. درمان شناختى رفتارى كلاسيك

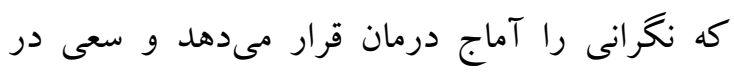
كاهش آن دارد، بنا به دليل مذكور در درمان اختلال

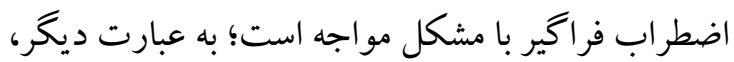
كاهش نخرانى براى افراد مبتلا به اختلال اضطراب فراگير به معناى از دست دادن سير محافظتى در برابر رويدادهاى احتمالى منفى آينده است نيومن و و به

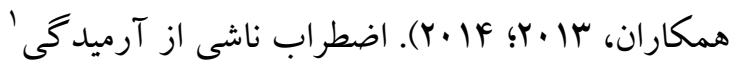
از اين ادعا حمايت مى كند؛ به اين معنى كه افراد مبتلا

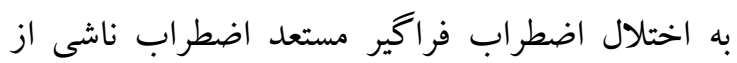
آرميدگى هستند، زيرا آرميدگى احتمال غافلگير شدن توسط تغييرات هيجانى منفى را افزايش مىدهد و واحئ

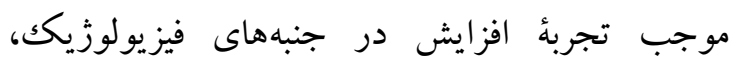
رفتارى و شناختى اضطراب مىشود (بوركووكى و و

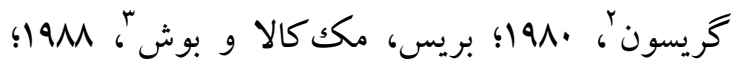



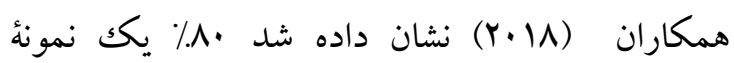
اختلال اضطراب فراگير كه آرميدگى تدريجى و ولن كاربردى را به عنوان بخشى از درمانشان دريافت كرده اصني

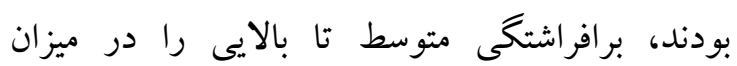
اضطراب ناشى از آرميدگى تجربه كردند. در مطالعات بردئ ديخر نيز نتايج مشابهى حاصل شد. براى مثلى مثال،

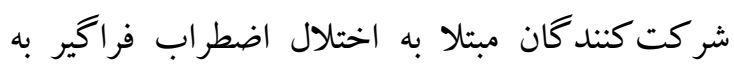
دنبال كاهش حالت هيجانى منفى خود با روشهاى ساز كارانه، بريشانى بيشترى را تجربه مى كردند (نيومن

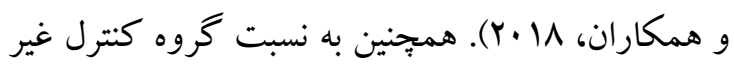

\footnotetext{
1. Relaxation-Induced Anxiety

2. Borkovec \& Grayson

${ }^{3}$. Braith, McCullough, \& Bush

4 . Heide
} 
هيجانى بايدار و اجتناب از تجربهُ تغيير هيجانى منفى بيشتر در صورت وقوع بيامد ترسناكك به كار مى گيرند. در مجموع، بر اساس مدل اجتناب از تغيير، راهبرد

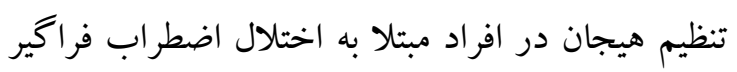

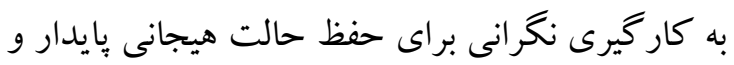
اجتناب از تغيير تُند و سريع در هيجان منفى است. برائ همجنين بنا بر آنجه كفته شد، سه اصل مطرحشده براى مدل اجتناب از تغيير از شواهد ئزوهشى قابلتوجهى

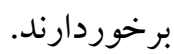

مقايسٔ مدل اجتناب از تغيير با ساير مدلهاى نغر انى و اختلال اضطر اب فراتير مديناب

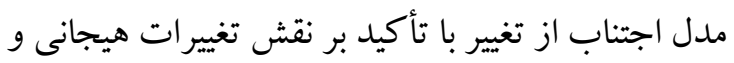

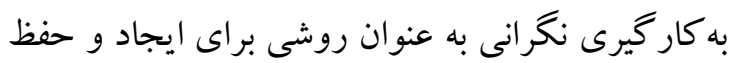
فعالانه حالت هيجانى منفى جهت اجتناب از تغييرات

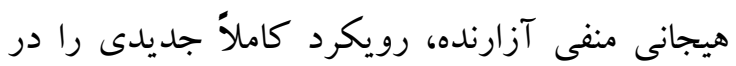

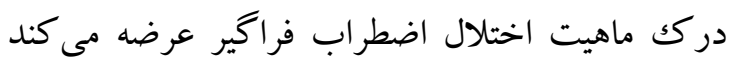
(نيومن و لرا، || (Y). اين مدل شباهتها و تفاوتهايى را با مدلهاى بيشين نكرانى و اختلال اضطراب فر فراخير

$$
\text { دارد كه در ادامه به آنها مى بردازيم. }
$$

مدلهاى كنونى اختلال اضطراب فراگير مفهومبردازىهاى متفاوتى از نخرانى و اختلال اضطراب

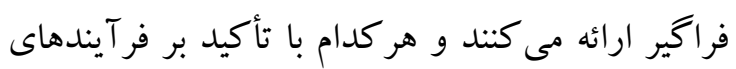
روانشناختى متفاوت، سعى در ارائه دقيقترين تبيينها و مؤثرترين روشهاى درمانى براى اين اختلال دارند.

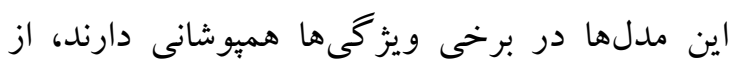

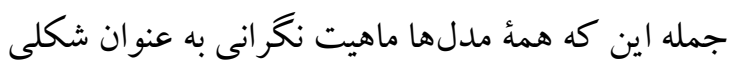
از افكار تكرارشونده در بِاسخ به افكار، احساسات و رويدادهاى راهانداز را مىيذيرند، نگگرانى را به عنوان روشى براى مقابله با رويدادهاى منفى احتمالى در آينده در نظر مى گيرند، اتفاق نظر دارند كه نغرانى يردازش هيجانى را مختل مى كند و به غير از مدل
اتفاقات ناخوشايند احتمالى آمادگى هيجانى نداشته باشد و آن اتفاق ناخوشايند رخ دهد، ميزان تغيير هيجانى منفى كه تجربه مى شود بيشتر از زمانى است كه

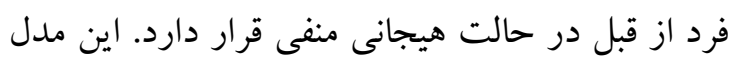

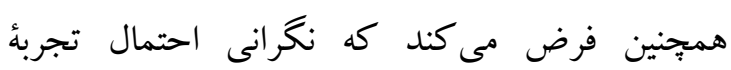
تغييرهاى هيجانى مثبت را افزايش ميدهد. تغيير هيجانى مثبت زمانى اتفاق مىافتد كه فرد در مورد يكك

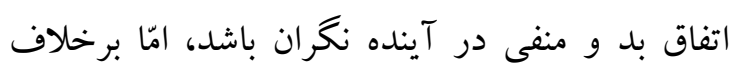

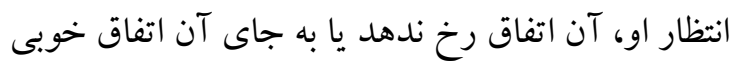
رخ دهد. در اين حالت هيجان او از يكك حالت منفى

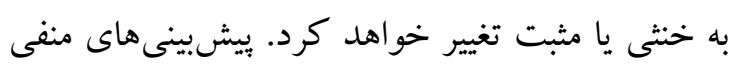

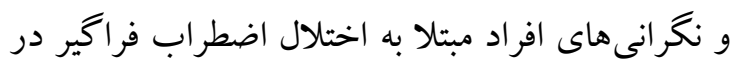
هـ-191\% موارد به واقعيت نمى ييوندد (بور كووكى، هاسلت- استيونز و دياز'، 1999)، از اينرو احتمال تجربهُ تغيير هيجانى مثبت در اين افراد بالا است. هنگامى كه فرد مبتلا به اختلال اضطراب فراكير تغيير هيجانى مثبت را تجربه كرد، به اين معنى است كه

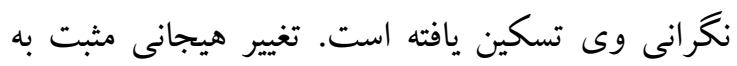

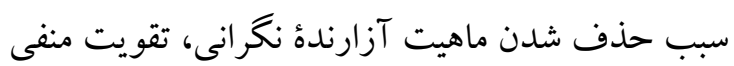
دريافت مى كند. اين تقويت منفى يكك جرخهُ معيوب شكل مىدهد، به اين صورت كه فرد مبتلا به اختلال اضطراب فراكير از طريق نخرانى در مورد بيامد ترسناكك حالت هيجانى منفى براى خود ايجاد مى كند و با رخ ندادن آن اتفاق ترسناكك يا رخ دادن اتفاق

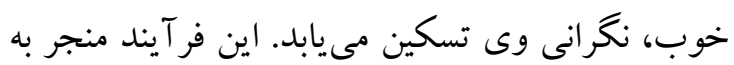

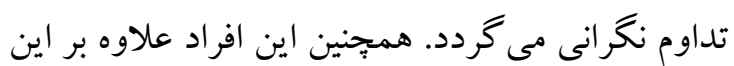
كه فعالانه از نكرانى براى از بين بردن احتمال تجربه

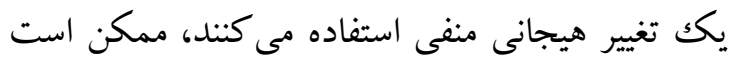

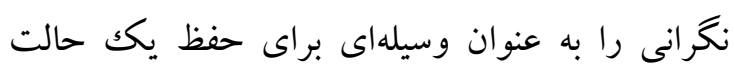

\footnotetext{
${ }^{1}$. Borkovec, Hazlett-Stevens, \& Diaz
} 
اين نكته اتفاق نظر دارند كه علت ناراحتى و آشفتخى

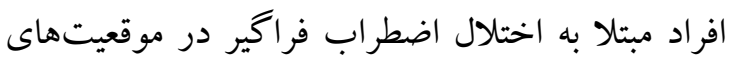
بلاتكليف، ترس از عواقب اين تجربه منفى (بلاتكليفى)

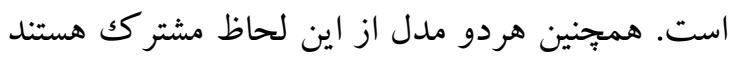
كه عاملهايى مانند انتظار وقوع يِيامدهاى منفى و جهت گيرى منفى نسبت به مشكل راعلّت گرايش افراد مبتلا به اختلال اضطراب فراگير به داشتن احساس ناخوشايند مداوم جهت به حداقل رساندن احتمال

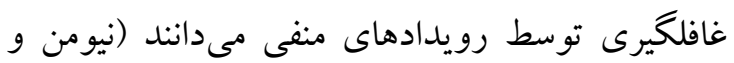
كرا، (1)

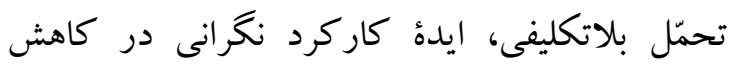

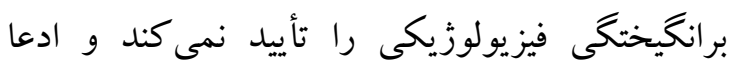


اختلال اضطراب فراخير از طريق آن و به شكل فعّال، حالت هيجانى منفى و اضطراب را ايجاد و حفظ براب مى كنند. مدل اجتناب از تغيير مطرح مى كند كه بخش عمدهُ عدم تحمّل بلاتكليفى، ناشى از اين حقيقت است كه ترس اين افراد، علاوه بر عواقب بيرونى رويداد

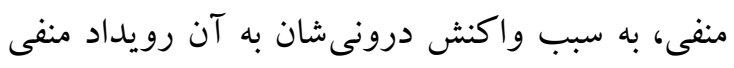
(يكك تغيير هيجانى منفى) است. براى مثال اخر فرد به

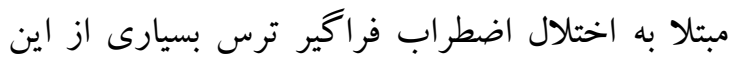
داشته باشد كه به يكك بيمارى مبتلا شود و دشوارى بهر بهري زيادى در تحمّل بلاتكليفى ناشى از اين بيامد تجربه كند، در اين صورت ترجيح مىدهد به منظور مقابله با اين بلاتكليفى يكك واكنش درونى در خودش ايجاد كند كه مشابه واكنش وى در صورت بلن روى دادن آن

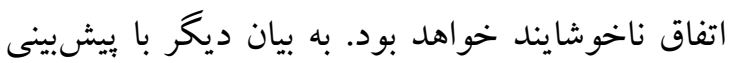

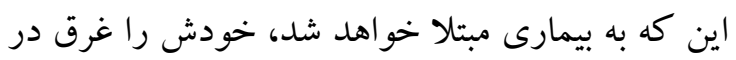
حالت هيجانى منفى مى كند جرا كه به اين روش، ديخر انتظار وقوع رويداد منفى را در موقعيتى مبهم نخواهد داشت؛ بنابراين مدل اجتناب از تغيير مطرح مى كند كه



بدتنظيمى هيجان، همةُ مدلهاى ديخر مطرح مى كنند

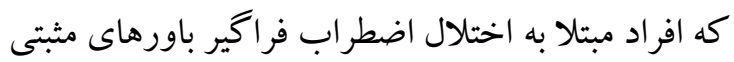
در مورد سودمندى نكرانى دارند. همجنين مدلهاى كنونى در اين نكته اتفاق نظر دارند كه نخرانى راهى براى اجتناب از عاطفهُ منفى است. به طور اختصاصى تر، مدل اجتناب شناختى كه توسط بوركووك ارائه شد، تحليلى رفتارى از نخرانى و اختلال اضطراب فراخير ارائه مىدهد. اين مدل مطرح مى كند كه ياسخ فرد به به تهايدها و خطرات شناسايىشده از طريق نخرانى، موجب كاهش اضطراب و آشفتكى و در نتيجه تقويت

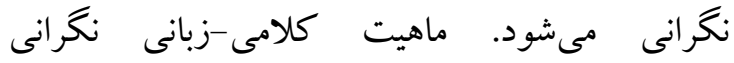
برانگيختخى فيزيولوزيكى را كاهش مىدهد و مانع مانع يردازش هيجانى مىشود. مدل اجتناب از تغيير خلاف اين ادعا را دارد و نغرانى را مهمترين عامل در ايجاد و حفظ حالت هيجانى منفى و بايدار براى اجتناب از تغيير هيجانى منفى، معرفى مى كند.

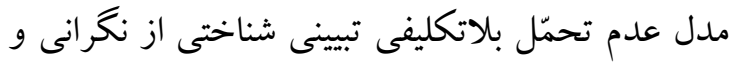

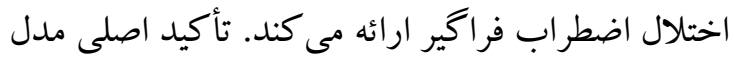
عدم تحمّل بلاتكليفى بر اين نكته است كه افراد مبتلا به اختلال اضطراب فراكير حساسيت بالايى نسبت به موقعيتها و رويدادهاى بلاتكليف و غيرقطعى دارند و

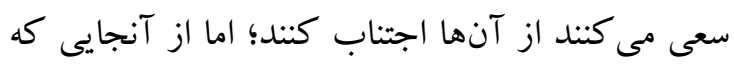

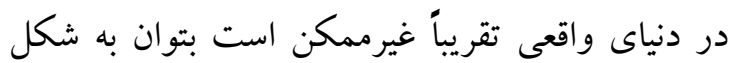
رفتارى از موقعيت هاى بلاتكليف اجتناب كرد، به همين



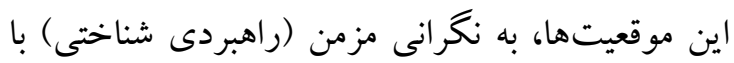
هدفِ اجتناب از ناراحتى و آشفتكى يناه مى آورند.

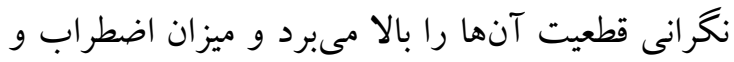

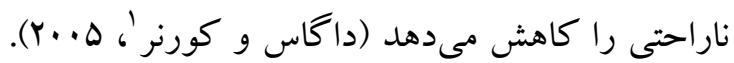
مدل عدم تحمّل بلاتكليفى و مدل اجتناب از تغيير در

${ }^{1}$. Koerner 
دو مدل بر وجود باورهاى مثبت و منفى در مورد نغرانى تأكيد دارند و افراد مبتلا به اختلال اضطراب فراخير نخرانى را به عنوان روشى براى مقابله با تهلديدها

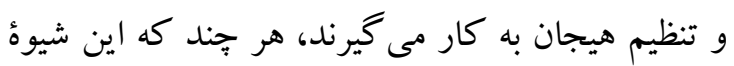

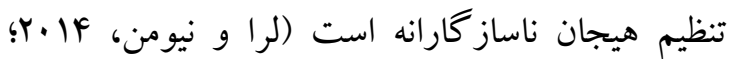
ولز، و.+Y). همجنين مدل اجتناب از تغيير با مدل

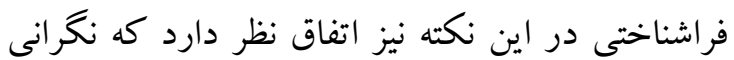
بيش از يكك سطح دارد، اما بر اساس مدل اجتناب از تغيير، نقش محافظت كنندهُ نخر انى در برابر تجربهُ تغيير هيجانى منفى، منجر به شروع و ادامهُ نخرانى مىشود.

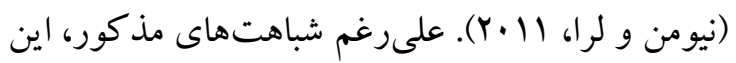
دو مدل از اين لحاظ با هم فرق دارند كه مدل

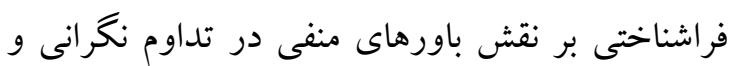

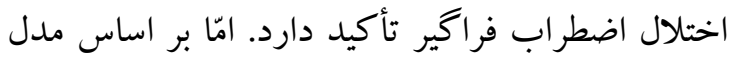

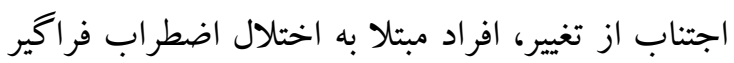
معتقدند كه نخرانى در كنترل باسخهاى هيجانى آنها به رويدادهاى بيرونى سودمند است (بوركووكى و


همانند مدل اجتناب شناختى نكخر انى و مدل عدم تحمّل

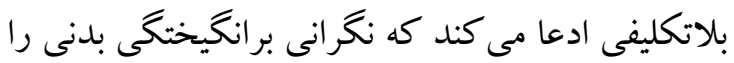

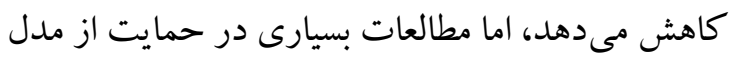

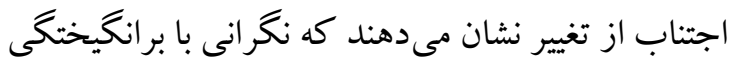
بدنى مداوم ارتباط دارد (نيومن و لرا، II (Y). تأكيد مدل بد تنظيمى هيجان بر وجود مشكلات تنظيم

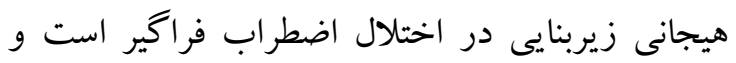
نقاط مشتركى با مفهومسازى لينهان از مشكلات تنظيم هيجان در اختلال شخصيت مرزى دارد (جإيمن،

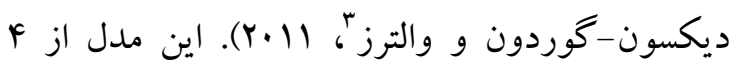
مؤلفه شدت هيجانها، فهم هيجانى ضعيف، واكنش شناختى منفى به هيجانها و ر راهبردهاى ناساز كارانه

${ }^{2}$. Roemer

${ }^{3}$. Chapman, Dixon-Gordon, \& Walters
نكرانى مزمن، خودشان را به لحاظ هيجانى براى رويارويى با رويداد منفى آماده مى كنند. اين آمادكى مئى آنها را از تجربهُ آزارندهُ تغيير هيجانى منفى محافظت مى كند كه منجر به تقويت جرخهُ معيوب مىشود. درمجموع اين همان فرآيندى است كه بر اساس مدل اجتناب از تغيير منجر به تداوم نخرانى مىشود (نيومن و

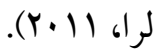
مدل فراشناختى مطرح مى كند كه افراد مبتلا به اختلال

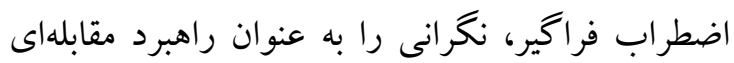
اصلى برمى ززينند و باورهاى مثبتى در مورد سودمندى

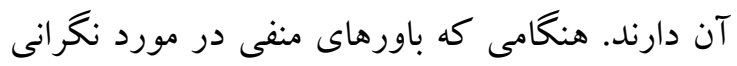
به خصوص باورهاى مربوط به كنترل نايذيرى و

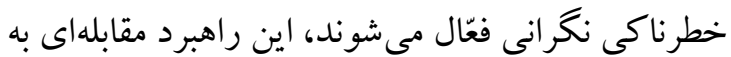

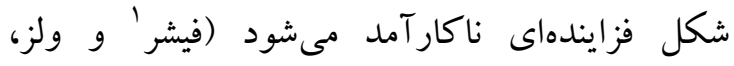

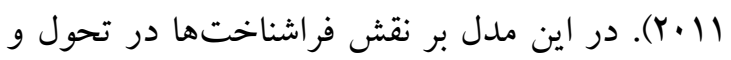
تداوم اختلال اضطراب فراگير تأكيد شده است. شكل گيرى فرا نگر انى يا نخر انى دربارهُ نخر انى، منجر به تحوّل و تداوم اختلال اضطراب فراگير مىشود؛ زيرا

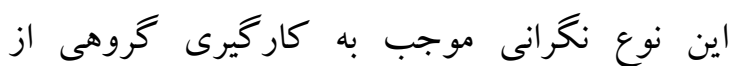
راهبردهاى ناكار آمد اجتناب از نكرانى (مانند، اطمينان طلبى، سركوب فكر، اجتناب از موقعيتهاى نخران-


مدل فراشناختى همعقيده است كه باورهاى مثبت در مورد نخر انى، به كار گيرى آن به عنوان راهبرد مقده مقابلهاى ناساز گارانه را تقويت مى كند و اين راهبرد، در نهايت مانع بردازش هيجانى ترس مىشود. همجنين مدل اجتناب از تغيير ادعاى مدل فراشناختى را مىيذيرد كه فر آيند نكرانى براى افراد جرخهُ معيوبى شكل مىدهد

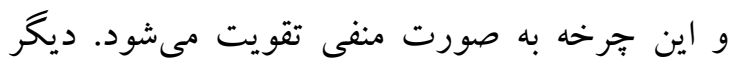
ويز گىهاى مشتر كى اين مدلها عبارتاند از اين كه هر

${ }^{1}$. Fisher 
ادراكك كنند. در مجموع ارزيابى منفى افراد مبتلا به اختلال اضطراب فراكير از تغيير هيجانى منفى است كه أنه منجر به مشكلاتى در تنظيم هيجان شود. اين مشكلات تنظيم هيجان مى تواند موجب شود شدّت ذهنى هيجان و دركك آن در اين افراد نابهنجار باشد (نيومن و لرا،

مدل مبتنى بر بذيرش نيز از F مؤلفه تشكيل شده است كه عبارتاند از: (1) تجارب درونى (افكار، احساسات يا حسهاى بدنى)؛ (Y) يكك رابطة مشكل آفرين با تجارب درونى كه شامل دو جنبة اختصاصى است: (I) واكنش منفى به تجارب درونى و (II) آميختخى با تجارب درونى؛ (r) اجتناب تجربهاى، به اين نكته اشاره دارد كه فرد به صورت فعال يا خودكار از تجارب درونى كه تهلديدكننده يا منفى ادراكك مىشوند، اجتناب مى كند و (f) محدوديت رفتارى، به معنى درگيرى كمتر در اعمال يا فعاليتهاى ارزشمند است. بر اساس اين مدل افراد مبتلا به اختلال اضطراب فراخير واكنشهاى منفى نسبت به تجارب درونىشان نشان

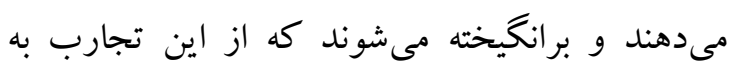
شكل رفتارى و شناختى (از طريق به كارگيرى مكرر فرآيند نگرانى) اجتناب كنند (روئمر، سالترز، رافا و

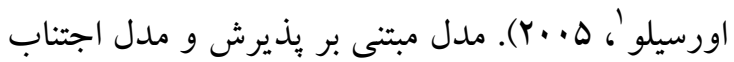
از تغيير از اشتراكات زيادى برخوردار هستند و بر خايههاى نظرى مشابهى بنا شدهاند. مطابق اين دو مدل

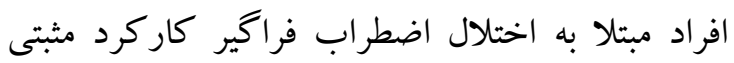
براى نگرانى قائل هستند. مدل اجتناب از تغيير نيز مانند

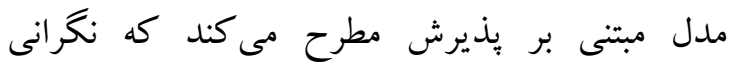
كاركردى اجتنابى دارد و از طريق تقويت تداوم مىيابد. همجنين نظريهيردازان مدل اجتناب از تغيير موافق هستند كه افراد مبتلا به اختلال اضطراب فراخير

\footnotetext{
${ }^{1}$. Salters, Raffa, \& Orsillo
}

تنظيم و مديريت هيجانها تشكيل شده است و مطرح مى كند كه افراد مبتلا به اختلال اضطراب فراخير مشكلاتى را در اين مؤلفهها تجربه مى كنند. در اين مدل، نكرانى به عنوان تلاشى براى اجتناب از تجارب هيجانى آزاردهنده و راهبرد تنظيم هيجان در نظر كرفته مىشود (منين و همكاران، هـ·r). مدل بد تنظيمى هيجان و مدل اجتناب از تغيير به طور يكسان ادعا مى كنند كه افراد مبتلا به اختلال اضطراب فر هراخير در تنظيم مناسب هيجان مشكل دارند و اين ضعف در تنظيم هيجان، مانع بردازش هيجانى ترس مىشود.

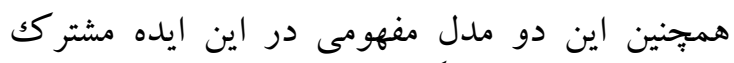

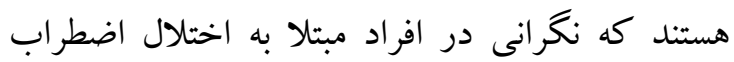
فراگير، وسيلهاى ناكار آمد براى مقابله با تهديدها و نيز تنظيم هيجان است. بهعلاوه، مدل اجتناب از تغيير نيز اين نكته را مىيذيرد كه اين افراد هيجانها را با شدّت بالايى تجربه مى كنند (نيومن و لرا، Iالب). اين دو مدل از اين نظر با هم تفاوت دارند كه ديدكاههاى متفاوتى لئى را در زمينهُ تهلديد خاص ناشى از هيجان و همجنين نقش و كاركرد نغرانى در تداوم اختلال اضطراب فراخير و مشكلات تنظيم هيجان ارائه مى كنند (نيومن و

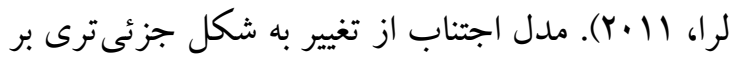
ارزيابى منفى از تغييرات هيجانى منفى تأكيد مى كند. بر اساس اين مدل موضوع اصلى ترس، تغيير هيجانى منفى است. احساس آسيبذيذير بودن و آمادگى نداشتن براى

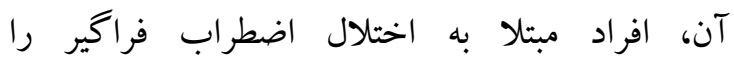
برمىانگيزد كه از طريق نخرانى حالت هيجانى منفى را ايجاد و حفظ كنند تا بتوانند از اين نوع تغيير هيجانى

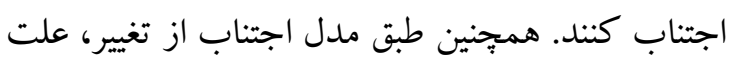
اين كه افراد مبتلا به اختلال اضطراب فراخير هيجانهاى خود را شديدتر توصيف مى كنند اين است كه تجربه تغيير هيجانى منفى براى آنها آزاردهنده است و موجب مىشود هيجانهاى منفى را به صورت شديد 
مىشود، هرجند با حفظ آن بيمار هميشه در وضعيت

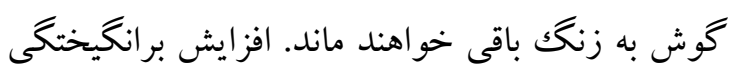
فيز يولوزيكك ناشى از نكرانى از ديد كاه مدل اجتناب از تغيير با كاهش تغييريذيرى واكنشهاى بدنى همراه است، موضوعى كه در مطالعات بىشمارى به آن اشاره

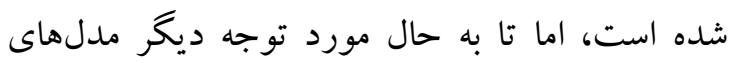
نظرى قرار نخرفته بود. بر اساس مدل اجتناب از تغيير، هيجان منفى دائمى براى افر اد مبتلا به اختلال اضطراب

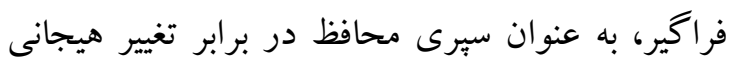
منفى عمل مى كند، اما تغيير هيجانى مثبت (تغيير حالت



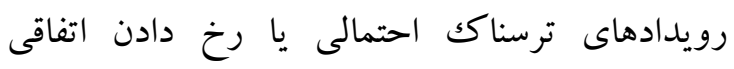
خوشايند تجربه مىشود، موجب تداوم نخرانى مىشود. مدل اجتناب از تغيير مفروضههاى اساسى برخى از

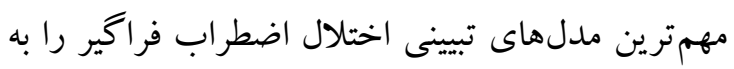
جالش كشيده است. هرجّند براى برخى از اين جالشها شواهدى نيز ارائه كرده است امّا به عنوانى مدلى جديد نياز به جمع آورى و انتشار يافتهاى بيشترى دارد.

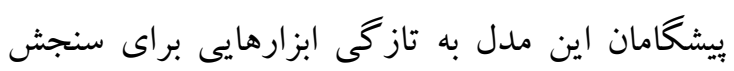

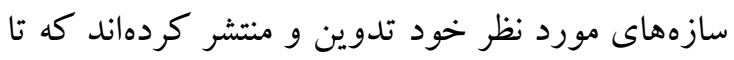
به اكنون، تنها در جمعيت دانشجويان آمريكايى شواهدى در تأييد آن منتشر نشده است. در ادبيات يثزوهشى حوزهُ اختلال اضطراب فراخير هنوز مطالعات مقايسهاى تجربى به منظور بررسى اين مدل با مدلهاى ديخر صورت نگر فته است. اخيراً مطالعاتى انتشار يافته بنه است كه اجتناب از تغيير را در اختلالهاى هيجانى

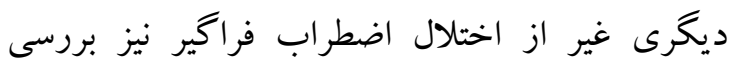

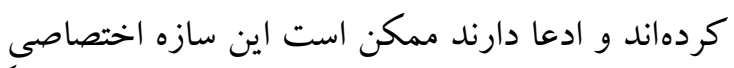
اين اختلال نباشد و به عنوان سازهاى فراتشخيصى بتوان

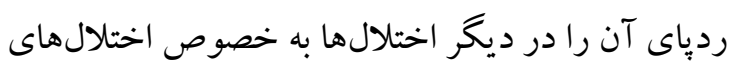
هيجانى ردگيرى كرد. مسئله ديخر قابل طرح در مورد

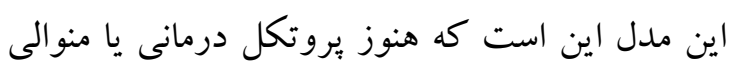

از نخر انى براى كنترل هيجانها استفاده مى كنند كه مانع

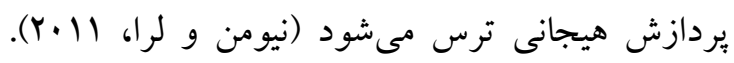
برخلاف مدل مبتنى بر يذيرش، عمدهترين ترس افراد

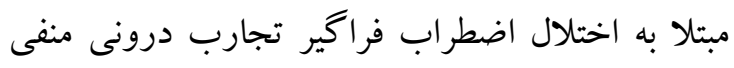
نيست، بلكه تغيير هيجانى منفى است. اخر جه مدل مدل مبتنى بر بذيرش، اجتناب هيجانى را عامل تقويت

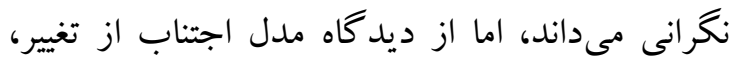

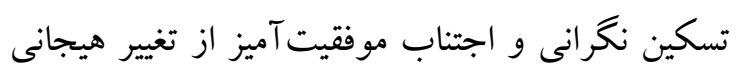
منفى (در صورتى كه اتفاق ترسبرانگيز رخ دهد و فرد تغيير هيجانى منفى را تجربه نكند) است كه جروخ نكر انى را تقويت مى كند و موجب تداوم آن مىشود.

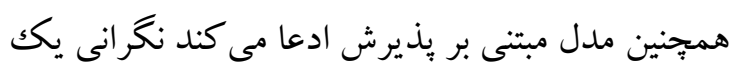

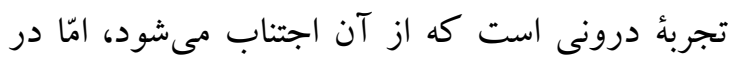
مقابل مدل اجتناب از تغيير مطرح مى كند نغرانى و دونى برانگيختخى همراه آن محافظى در برابر تجربهُ تغيير هيجانى منفى است (نيومن و لرا، II (Y). مدل اجتناب از تغيير بر خلاف مدلهاى تبيين كننده اختلال اضطراب فراگير معتقد است كه ترس عمده بيماران مبتلا به اين اختلال، تغيير ناگهانى حالت هيجانى از خنثى/مثبت به منفى است. تغيير هيجانى منفى براى افراد مبتلا به اختلال اضطراب فرئ فراخير آزاردهنده است كه منجر به باسخدهى هيجانى شديدتر و در نتيجه مشكلات بد تنظيمى هيجانى مىشود، به

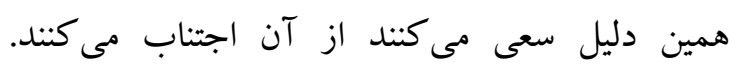
نخرانى به عنوان عنصر مشترك در تمامى مدلهاى تبينى اختلال اضطراب فراكير شناخته شده است و هر مدل براى آن نقشى قائل شده است. در مدل اجتناب از تغيير، نقش نكرانى ايجاد و حفظ عاطفهُ منفى و وپايدار است كه به اين طريق مانع تجربهُ تغيير هيجانى منفى لئى لئى 
(2015). Emotion reactivity and regulation in late-life generalized anxiety disorder. functional connectivity at baseline and posttreatment. Am J Geriatr Psychiatry, 23(2), 200-214. doi:10.1016/j.jagp.2014.05.003.

Arbel R, Shapiro LS, Timmons AC, Moss IK, \& Margolin G. (2017). Adolescents' Daily Worry, Moming Cortisol, and Health Symptoms. Journal of Adolescent Health, 60(6), $667-673$. doi:https:/doi.org/10.1016/j.jadohealth.2017 .01 .007 .

Bacon MM, RoodEA, \& Washbum MF. (1914). A study of affective contrast. (Minor Stud. fr. Psychol. Lab. of Vassar Col., XXV.). The American Joumal of Psychology, 25, 290293. doi:10.2307/1413417.

Ballenger JC, Davidson JR, Lecrubier Y, Nutt DJ, Borkovec TD, Rickels K, Wittchen HU. (2001). Consensus statement on generalized anxiety disorder from the Intemational Consensus Group on Depression and Anxiety. J Clin Psychiatry, 62 Suppl 11, 5358.

Bandelow B, Boemer JR, Kasper S, Linden M, Wittchen HU, \& Moller HJ. (2013). The diagnosis and treatment of generalized anxiety disorder. Dtsch Arztebl Int, 110(17), 300-309; quiz 310. doi:10.3238/arztebl.2013.0300.

Bandelow B, \& Michaelis S. (2015). Epidemiology of anxiety disorders in the 21st century. Dialogues in clinical neuroscience, 17(3), 327-335.

Barger SD, \& Sydeman SJ. (2005). Does generalized anxiety disorder predict coronary heart disease risk factors independently of major depressive disorder? Journal of affective disorders, 88(1), 87-91.

Beesdo K, Pine DS, Lieb R, \& Wittchen HU. (2010). Incidence and risk pattems of anxiety and depressive disorders and categorization of generalized anxiety disorder. Arch Gen Psychiatry, 67(1), 47-57. doi:10.1001/archgenpsychiatry.2009.177.

Behar E, DiMarco ID, Hekler EB, Mohlman J, \& Staples AM. (2009). Current theoretical models of generalized anxiety disorder (GAD): conceptual review and treatment

$$
\begin{aligned}
& \text { بر اساس آن طراحى نشده است تا بتوان صحت ادعاى } \\
& \text { ارائه كنندكان آن را در بالين آزمون كرد. اين مدل } \\
& \text { هنوز در ساحت نظرى در حال رشد و توسعه است امّا }
\end{aligned}
$$



$$
\begin{aligned}
& \text { ادعاى يركردن شكاف نظرى و درمانى در اين اختلال } \\
& \text { را دارد، بايد تبديل به بروتكل و كتابجههايى شود تا لتر } \\
& \text { بتوان آن رادر ساحت بالين نيز آزمود. } \\
& \text { شايد نكته مهم و قابل طرح ديخر در اين زمينه فقدان } \\
& \text { ديدگاهى رشدى به سازههاى طرح شده در اين مدل } \\
& \text { باشد. به عنوان مثال، اجتناب از تغيير جِكونه رشد و و }
\end{aligned}
$$

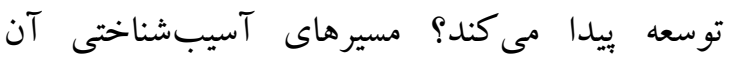

$$
\begin{aligned}
& \text { كدامند؟ از طريق جه ميانجىهاى با علائم اختلالهاى } \\
& \text { هيجانى بيوند بيدا مى كنند؟ در روند تحولى از جه بِيأ } \\
& \text { سرشتى نشأت مى گيرند؟ با وجود محدوديتهاى گفته }
\end{aligned}
$$

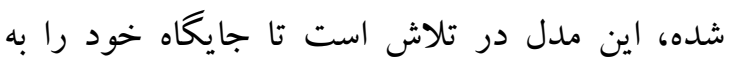

$$
\begin{aligned}
& \text { عنوان مدلى جايخزين در اختلال اضطراب فراخير و } \\
& \text { شايد ديخر اختلالهاى اضطر ابى تحكيم بخشد. }
\end{aligned}
$$

\section{References}

Aldao A, \& Mennin DS. (2012). Paradoxical cardiovascular effects of implementing adaptive emotion regulation strategies in generalized anxiety disorder. Behav Res Ther, 50(2), 122-130. doi:10.1016/j.brat.2011.12.004.

Alonso J, Angermeyer MC, Bemert S, Buffaerts R, Bugha TS, Bryson H, Vollebergh WA. (2004). Use of mental health services in Europe: results from the European Study of the Epidemiology of Mental Disorders (ESEMeD) project. Acta Psychiatr Scand Suppl(420), 47-54. doi:10.1111/j.16000047.2004.00330x.

American Psychiatric Association. (2013). Diagnostic and statistical manual of mental disorders : DSM-5. Arlington, VA: American Psychiatric Association.

Andreescu C, Sheu LK, Tudorascu D, Gross JJ, Walker S, Banihashemi L, \& Aizenstein $\mathrm{H}$. 
implications. J Anxiety Disord, 23(8), 10111023. doi:10.1016/j.janxdis.2009.07.006.

Borkovec TD, \& Grayson JB. (1980). Consequences of Increasing the Functional Impact of Internal Emotional Stimuli. In K. R. Blankstein, P. Pliner, \& J. Polivy (Eds.), Assessment and Modification of Emotional Behavior (pp. 117-137). Boston, MA: SpringerUS.

Borkovec TD, Hazlett-Stevens H, \& Diaz ML. (1999). The role of positive beliefs about worry in generalized anxiety disorder and its treatment. Clinical Psychology \& Psychotherapy, 6(2), 126-138. doi:10.1002/(SICI)1099-

0879(199905)6:2<126::AID-

CPP193>3.0.CO;2-M.

Borkovec TD, \& Roemer L. (1995). Perceived functions of worry among generalized anxiety disorder subjects: distraction from more emotionally distressing topics? J Behav TherExpPsychiatry, 26(1), 25-30.

Bourgeois ML, \& Brown TA. (2015). Perceived Emotion Control Moderates the Relationship between Neuroticism and Generalized Anxiety Disorder. Cognit Ther Res, 39(4), 531-541. doi:10.1007/s10608015-9677-5.

Braith JA, MoCullough JP, \& Bush JP. (1988). Relaxation-induced anxiety in a subclinical sample of chronically anxious subjects. $\mathbf{J}$ Behav TherExpPsychiatry, 19(3), 193-198.

Brown TA, \& Naragon-Gainey K. (2013). Evaluation of the unique and specific contributions of dimensions of the triple vulnerability model to the prediction of DSM-IV anxiety and mood disorder constructs. Behav Ther, 44(2), 277-292. doi: 10.1016/j. beth. 2012.11.002.

Buff C, Brinkmann L, Neumeister P, Feldker K, Heitmann C, Gathmann B, Straube T. (2016). Specifically altered brain responses to threat in generalized anxiety disorder relative to social anxiety disorder and panic disorder. Neuroimage Clin, 12, 698-706. doi:10.1016/j.nicl.2016.09.023.

Bui E, Anderson E, Goetter EM, Campbell AA, Fischer LE, Barrett LF, \& Simon NM. (2017). Heightened sensitivity to emotional expressions in generalised anxiety disorder, compared to social anxiety disorder, and controls. Cogn Emot, 31(1), 119-126. doi:10.1080/02699931.2015.1087973.

Capobianco L, Morris JA, \& Wells A. (2018). Worry and rumination: do they prolong physiological and affective recovery from stress? Anxiety Stress Coping, 31(3), 291303. doi:10.1080/10615806.2018.1438723.

Carter RM, Wittchen HU, Pfister H, \& Kessler RC. (2001). One-year prevalence of subthreshold and threshold DSM-IV generalized anxiety disorder in a nationally representative sample. Depress Anxiety, 13(2), 78-88.

Cassidy J, Lichtenstein-Phelps J, Sibrava NJ, Thomas CL, \& Borkovec TD. (2009). Generalized Anxiety Disorder: Connections With SelfReported Attachment. Behav Ther, 40(1), 23-38.

doi:https//doi.org/10.1016/j.beth.2007.12.00 4.

Chapman A, Dixon-Gordon K, \& Walters K. (2011). Experiential Avoidance and Emotion Regulation in Borderline Personality Disorder. 29, 35-52. doi:10.1007/s10942011-0124-6.

Crouch TA, Lewis JA, Erickson TM, \& Newman MG. (2017). Prospective investigation of the contrast avoidance model of generalized anxiety and worry. Behav Ther, 48(4), 544556.

Deschênes SS, Dugas MJ, \& Gouin JP. (2016). Intolerance of uncertainty, worry catastrophizing, and heart rate variability during worry-inducing tasks. Personality and Individual Differences, 90, 199-204. doi: https: //doi.org/10.1016/j. paid. 2015.11.015.

Dugas MJ, \& Koerner N. (2005). CognitiveBehavioral Treatment for Generalized Anxiety Disorder. Current Status and Future Directions. Joumal of Cognitive Psychotherapy, 19(1), 61-81. doi:10.1891/jcop.19.1.61.66326.

Dugas MJ, \& Robichaud M. (2007). Cognitivebehavioral treatment for generalized anxiety disorder. From science to practice. New York, NY, US: Routledge/Taylor \& Francis Group. 
Fisher P, \& Wells A. (2011). Conceptual Models of Generalized Anxiety Disorder. Psychiatr Ann, 41, 127-132. doi:10.3928/0048571320110203-11.

Fitzgerald JM, Phan KL, Kennedy AE, Shankman SA, Langenecker SA, \& Klumpp $\mathrm{H}$. (2017). Prefrontal and amygdala engagement during emotional reactivity and regulation in generalized anxiety disorder. $\mathrm{J}$ Affect Disord, 218, 398-406. doi:10.1016/j.jad.2017.05.013.

Glaser JP, van Os J, Portegijs PJ, \& Myin-Germeys I. (2006). Childhood trauma and emotional reactivity to daily life stress in adult frequent attenders of general practitioners. $\mathbf{J}$ Psychosom Res, 61(2), 229-236. doi:10.1016/j.jpsychores.2006.04.014

Heide FJ, \& Borkovec TD. (1983). Relaxationinduced anxiety: Paradoxical anxiety enhancement due to relaxation training. Journal of Consulting and Clinical Psychology, 51(2), 171-182. doi:10.1037/0022-006X.51.2.171.

Kagan J, \& Snidman N. (1999). Early childhood predictors of adult anxiety disorders. Biol Psychiatry, 46(11), 1536-1541.

Kerns CE, Mennin DS, Farach FJ, \& Nocera CC. (2014). Utilizing an ability-based measure to detect emotion regulation deficits in generalized anxiety disorder. Joumal of Psychopathology and Behavioral Assessment, 36(1), 115-123. doi:10.1007/s10862-013-9372-3.

Kessler RC, DuPont RL, Berglund P, \& Wittchen HU. (1999). Impairment in pure and comorbid generalized anxiety disorder and major depression at 12 months in two national surveys. Am J Psychiatry, 156(12), 1915-1923. doi:10.1176/ajp.156.12.1915.

Kessler RC, Keller MB, \& Wittchen HU. (2001). The epidemiology of generalized anxiety disorder. Psychiatr Clin North Am, 24(1), 19-39.

Kim H, \& Newman M. (2016). Emotional contrast avoidance in generalized anxiety disorder and major depressive disorder: A comparison between the perseveration processes of worry and rumination. Paper presented at the 50th Annual Meeting of the
Association for Behavioral and Cognitive Therapies, New York, NY.

Lera SJ, \& Newman MG. (2010). Effects of worry on physiological and subjective reactivity to emotional stimuli in generalized anxiety disorder and nonanxious control participants. Emotion, 10(5), 640-650. doi:10.1037/a0019351.

Lera SJ, \& Newman MG. (2014). Rethinking the Role of Worry in Generalized Anxiety Disorder: Evidence Supporting a Model of Emotional Contrast Avoidance. Behav Ther, 45(3), 283-299. doi:https://oi.org/10.1016/j.beth.2013.12.01 1.

Mennin DS, Heimberg RG, Turk CL, \& Fresco DM. (2002). Applying an emotion regulation framework to integrative approaches to generalized anxiety disorder. Clinical Psychology: Science and Practice, 9(1), 8590. doi:10.1093/clipsy/9.1.85.

Mennin DS, Heimberg RG, Turk CL, \& Fresco DM. (2005). Preliminary evidence for an emotion dysregulation model of generalized anxiety disorder. Behav Res Ther, 43(10), 12811310. doi:10.1016/j.brat.2004.08.008.

Newman MG, Jacobson NC, Szkodny LE, \& Sliwinski MJ. (2016). Contrast avoidance in daily life. In T. M. Erickson, (chair), The contrast avoidance model: Reconceptualizing worry in GAD and as a transdiagnostic process. Paper presented at the Paper presented at the 50th Annual Meeting of the Association for Behavioral and Cognitive Therapies.

Newman MG, Lafreniere LS, \& Jacobson NC. (2018). Relaxation-induced anxiety: Effects of peak and trajectories of change on treatment outcome for generalized anxiety disorder. Psychotherapy research : joumal of the Society for Psychotherapy Research, 28(4), 616-629. doi:10.1080/10503307.2016.1253891.

Newman MG, \& Llera SJ. (2011). A novel theory of experiential avoidance in generalized anxiety disorder. A review and synthesis of research supporting a contrast avoidance model of worry. Clinical psychology review, 31(3), 371-382. 
Newman MG, Lera SJ, Erickson TM, \& Przeworski A. (2014). Basic science and clinical application of the Contrast Avoidance model in generalized anxiety disorder. Journal of Psychotherapy Integration, 24(3), 155.

Newman MG, Llera SJ, Erickson TM, Przeworski A, \& Castonguay LG. (2013). Worry and generalized anxiety disorder: a review and theoretical synthesis of evidence on nature, etiology, mechanisms, and treatment. Annual review of clinical psychology, 9, 275-297.

Newman MG, Shin KE, \& Zuellig AR. (2016). Developmental risk factors in generalized anxiety disorder and panic disorder. J Affect Disord, 206, 94-102. doi:10.1016/j.jad.2016.07.008.

Nordahl HM, Wells A, Olsson CA, \& Bjerkeset O. (2010). Association between abnormal psychosocial situations in childhood, generalized anxiety disorder and oppositional defiant disorder. Aust $\mathrm{N}$ Z J Psychiatry, 44(9), 852-858. doi: 10.3109/00048674. 2010.489504.

Noyes RJr. (2001). Comorbidity in generalized anxiety disorder. Psychiatr Clin North Am, 24(1), 41-55.

Ottaviani C, Thayer JF, Verkuil B, Lonigro A, Medea B, Couyoumdjian A, \& Brosschot JF. (2016). Physiological concomitants of perseverative cognition: A systematic review and meta-analysis. Psychol Bull, 142(3), 231-259. doi:10.1037/bul0000036.

Ottaviani C, Watson DR, Meeten F, Makovac E, Garfinkel SN, \& Critchley HD. (2016). Neurobiological substrates of cognitive rigidity and autonomic inflexibility in generalized anxiety disorder. Biol Psychol, 119, 31-41. doi: 10.1016/j. biopsycho. 2016.06.009.

Pieper S, Brosschot JF, van der Leeden R, \& Thayer JF. (2010). Prolonged cardiac effects of momentary assessed stressful events and worry episodes. Psychosom Med, 72(6), 570-577. doi:10.1097/PSY.0b013e3181dbc0e9.

Radstaak M, Geurts SA, Brosschot JF, Cillessen AH, \& Kompier MA. (2011). The role of affect and rumination in cardiovascular recovery from stress. International Joumal of Psychophysiology, 81(3), 237-244.

Roemer L, Salters K, Raffa SD, \& Orsillo SM. (2005). Fear and Avoidance of Internal Experiences in GAD: Preliminary Tests of a Conceptual Model. Cognitive Therapy and Research, 29(1), 71-88. doi:10.1007/s10608-005-1650-2.

Schienle A, Ebner F, \& Schäfer A. (2011). Localized gray matter volume abnormalities in generalized anxiety disorder. European Archives of Psychiatry and Clinical Neuroscience, 261(4), 303-307. doi:10.1007/s00406-010-0147-5.

Seeley SH, Mennin DS, Aldao A, McLaughlin KA, Rottenberg J, \& Fresco DM. (2016). Impact of Comorbid Depressive Disorders on Subjective and Physiological Responses to Emotion in Generalized Anxiety Disorder. Cognit Ther Res, 40(30), 290-303. doi:10.1007/s10608-015-9744-y.

Steinfurth EC, Alius MG, Wendt J, \& Hamm AO. (2017). Physiological and neural correlates of worry and rumination: Support for the contrast avoidance model of worry. Psychophysiology, 54(2), 161-171. doi:10.1111/psyp.12767.

Weise S, Ong J, Tesler NA, Kim S, \& Roth WT. (2013). Worried sleep: 24-h monitoring in high and low womiers. Biol Psychol, 94(1), 61-70. doi:10.1016/j.biopsycho. 2013.04.009

Wells A. (2006). The metacognitive model of worry and generalised anxiety disorder. Worry and its psychological disorders: Theory, assessment and treatment, 179-199.

Wichers M, Schrijvers D, Geschwind N, Jacobs N, Myin-Germeys I, Thiery E, van Os J. (2009). Mechanisms of gene-environment interactions in depression: evidence that genes potentiate multiple sources of adversity. Psychol Med, 39(7), 1077-1086. doi:10.1017/s0033291708004388.

Wittchen HU. (2002). Generalized anxiety disorder. prevalence, burden, and cost to society. Depression and Anxiety, 16(4), 162-171. doi:10.1002/da.10065.

Zhou Y, Cao Z, Yang M, Xi X, Guo Y, Fang M, Du Y. (2017). Comorbid generalized anxiety disorder and its association with quality of 
life in patients with major depressive doi:10.1038/srep40511. disorder. Scientific reports, 7, 40511-40511. 